\title{
Frequency of pathology in a large natural sample from Natural Trap Cave with special remarks on erosive disease in the Pleistocene
}

\section{La patologia osteoarticolare, con particolare riguardo a quella di tipo erosivo, nel Pleistocene: studio di un campione di reperti paleopatologici provenienti dalla Natural Trap Cave (Wyoming, USA)}

\author{
B.M. Rothschild ${ }^{1}$, L.D. Martin ${ }^{2}$ \\ ${ }^{1}$ The Arthritis Center of Northeast Ohio, University of Kansas Museum of Natural History, Carnegie Museum of Natural \\ History, Northeastern Ohio Universities College of Medicine and University of Akron; \\ ${ }^{2}$ Museum of Natural History and Department of Systematics and Ecology, University of Kansas, Lawrence, Kansas 66045
}

\begin{abstract}
RIASSUNTO
Nel presente studio vengono riportati i rilievi paleopatologici, con particolare riguardo alla presenza di artrite erosiva, di osteoartrosi, di DISH, nonché ai segni di danno della dentizione, relativi ad un'ampia popolazione di mammiferi, i cui resti (più di 30.000 ossa di 24 specie diverse) sono stati ritrovati nella Natural Trap Cave, Wyoming, USA. L'evidenza di artrite erosiva è confinata ai bovidi, Bison, Ovis e Bootherium, fatto osservabile anche in bisonti del tardo Pleistocene ritrovati nel Kansas (Twelve Mile Creek) e in un'altra località del Wisconsin, riferibile cronologicamente al primo Olocene. Questi dati, ovvero la restrizione di tali segni di patologia articolare ad un singolo genere animale (Bovidi) e ad un determinato periodo storico, rende plausibile l'ipotesi che un agente patogeno, identificabile col Mycobacterium tubercolosis, possa essere stato implicato nella genesi dell'artrite erosiva. Osteoartrosi e DISH sono risultate poco rappresentate nella popolazione animale della Natural Trap Cave, anche se il genere Bison ha dimostrato una discreta prevalenza di segni di osteoartrosi.

Lesioni della dentatura imputabili a difettosa manipolazione e masticazione delle ossa possono aver rappresentato un problema per gli animali carnivori. Uno di questi (Pantera atrox), con ogni probabilità, venne poi costretto da una malattia articolare ad un diverso stile alimentare, divenendo un animale saprofago.
\end{abstract}

Reumatismo, 2003; 55(1):58-65

\section{INTRODUCTION}

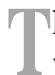
he search for the antiquity of erosive arthritis was the subject of an international conference (1). Although isolated examples have been reported from the anthropologic record $(2,3)$, systemic population studies have represented a newer approach (4). Recognition of erosive disease, osteoarthritis and DISH, as isolated observations, does not allow perspective with respect to popu-

Indirizzo per la corrispondenza:

Prof. Dr. B.M. Rothschild

The Arthritis Center of Northeast Ohio, 5500 Market Street,

Youngstown, $\mathrm{OH} 44512$, USA

E-mailbmr@neoucom.edu lation significance. Such perspective requires unbiased population sampling. Such an opportunity became available with the discovery of a late Pleistocene Natural Trap Cave in north-central Wyoming. The cave is an 85 foot deep bell-shaped depression occurring at an altitude of about 1,500 meters on a plateau (Little Mountain) in the bighorn Mountains, northeast of Lovell, Wyoming. The cave entrance (measuring 4 by 5 meters) is located on a game trail and is not visible until the edge is reached (Fig. 1, a-b) (5). Therefore, relatively unbiased sampling is available with respect to herds, packs and individuals utilizing that trail. The distance of the fall (28 meters) and lack of an alternative cave exit precluded escape or survival, and there is no convincing evidence that any 


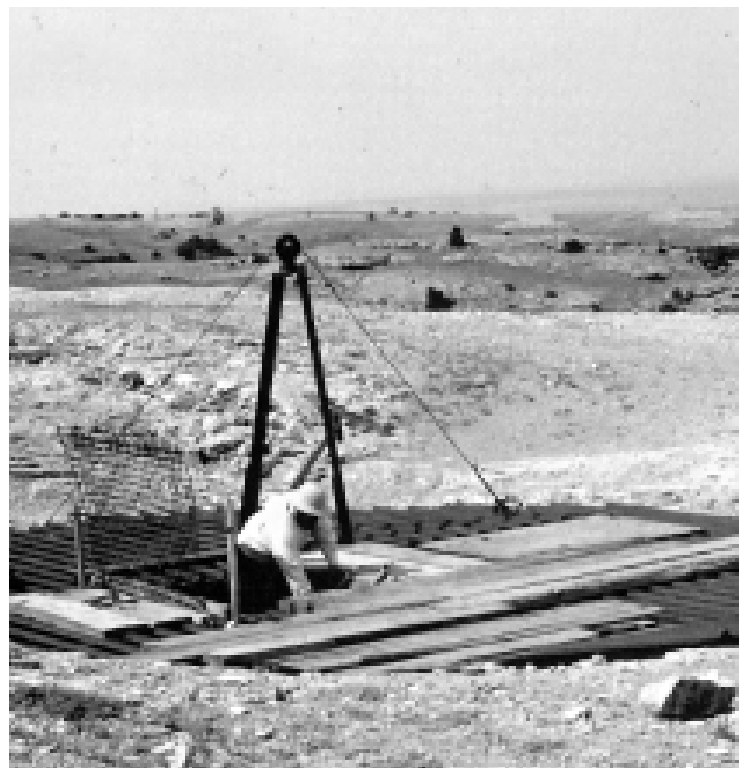

Figure 1a,b - Surface and descent views of Natural Trap Cave.

larger animal survived the fall. The inaccessibility of the cave base (without special equipment) precluded or minimized human and animal disturbance of the remains. Deposits, ranging in age from the recent to over 110,000 years ago, are present (Tab. I).

Table I - Surveyed Taxa from Natural Trap Cave.

Arctodus simus* (Short-faced bear)
Panthera atro** (American lion)
Micracinonyx trumani* (American cheetah)
Canis diris* (Dire wolf)
Canis lupus (Gray wolf)
Gulo gulo (Wolverine)
Martes nobilis* (Noble marten)
Marmota flaviventris (Yellow-bellied marmots)
Microtus montanus (Montane vole)
Microtus ochrogaster (Prairie vole)
Lagurus curatus (Sagebrush vole)
Antilocapra americana (Pronghorn antelope)
Equus sp.* (Five extinct species of Pleistocene horses)
Camelops (American camel)
Ovis canadensis catclawensis (Bighorn sheep)
Bison antiquus* (Bison)
Bootherium bombifrons* (Woodland muskox)
Mammuthus sp.* (Mammoth)
Brachylagus sp. (Pygmy rabbit)
Lepus sp. (Jack rabbit)
Sylvilagus sp. (Cottontail rabbit)
*Extinct taxa

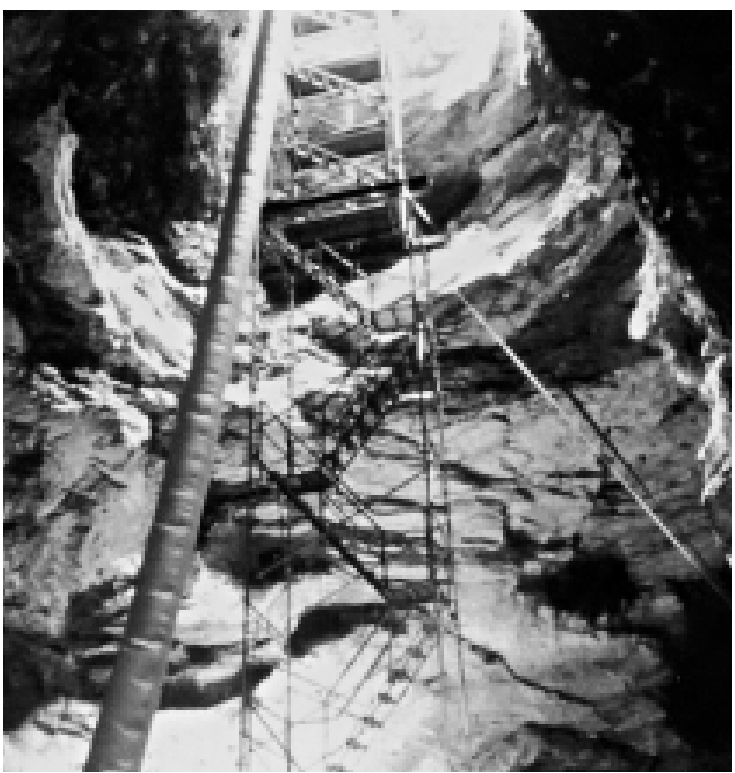

\section{MATERIALS AND METHODS}

The fossil fauna excavated from Natural Trap Cave (Table I) were subjected to systemic examination for the presence of bone pathology. To assess the reproducibility of the paleo-epidemiology of erosive disease, two additional sites were examined. The Twelve Mile Creek site, dated at 10,435 \pm 260 years before present (6), represents a kill site wherein at least 10 Bison antiquus were stampeded over the edge of a ravine. Specimens from the Intrastate Bison Site of Wisconsin, a late Pleistocene or early Holocene bog site (Milwaukee Public Museum) (7), were also examined. The University of Kansas contemporary mammalian collection was also reviewed for evidence of erosive disease in Bison.

All post-cranial bones were examined for disruption of articular surfaces and bone reaction along diaphyses. Osteoarthritis was recognized on the basis of diarthrodial joint osteophytes (8-10). Diffuse idiopathic skeletal hyperostosis (DISH) was recognized on the basis of ossification of longitudinal ligaments of the spine $(4,11-14)$.

\section{RESULTS}

Erosive disease was limited in distribution in the Natural Trap Cave fauna to three genera recovered from the 17,000 to 20,000 year level: Bison sp. 

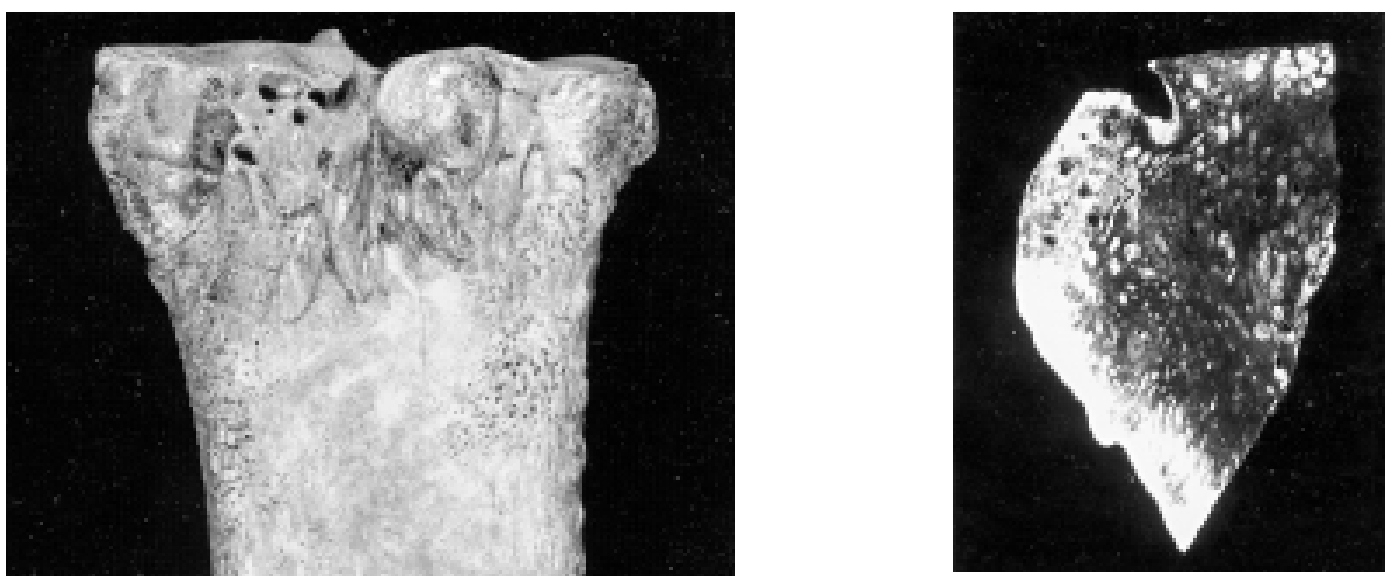

Figure 2a,b - Right metacarpal of Bison antiquus (KUVP 53361) from Natural Trap Cave: A) Posterior view of the proximal end, showing extensive erosion lesions; B) Section cut through lesions.

(Extinct bison), Ovis (extinct bighorn sheep), and Bootherium (extinct Muskox). Twelve of eighty Ovis metacarpals, three of the six Bison rnetacarpals and three of the five Bootherium metatarsals demonstrated erosions undermining the proximal articular surface (Figure 2). Eight of twenty rnetacarpals from the Twelve Mile Creek site and six of 24 metacarpals from the Intrastate Bison Site manifested similar erosive disease. Periosteal reaction was minimal, when present (Fig. 2, a-b). Radiologic examination revealed perierosive osteopenia, but no reactive sclerosis. Pathologic examination of cross-sections of eroded areas confirmed the radiologic findings. Reactive bone formation and peri-lesional sclerosis were notable by their absence.

Osteoarthritis (OA) was found in Gulo, Micracinonyx, Equus, Ovis, and Bison. A minimum of four wolverines, Gulo gulo, were represented by six femoral heads of which one (17\%) manifested osteophytes of osteoarthritis. Among minimum number of twenty wolves, Canis lupus, show one occurrence in thirty-five phalanges $(0.3 \%)$. Among minimum number of ten American cheetahs, $\mathrm{Mi}$ cracinonyx trumani, was one occurrence of osteoarthritis in 18 humeri (6\%). The American Lion, Short-faced Bear and Noble marten were free of osteoarthritis. In general, carnivores are rarely affected.

The ungulates had a much higher incidence of osteoarthritis. The horses varied in weight from two to three hundred kilograms. A minimum of seventy-six individuals are represented. Osteoarthritis was found in six of eighty-eight radioulnae (7\%); eight of one hundred and nine ectocuneiforms
(7\%); ten of eighty-one humeri (11\%); eight of sixty-two femoral heads (13\%); three of eighty-three pelvi (4\%); and one calcaneum of one hundred forty-two $(0.7 \%)$. The Pleistocene bighorn sheep, Ovis canadensis catclawensis, had three occurrences in eighty animals (4\%). The highest incidence was in the Pleistocene bison, Bison antiqu$u s$, with one in four humeri (25\%), two in four distal femora (50\%), three in six metatarsals $(50 \%)$, one in three astragalae (33\%), two in nine calcaneae $(22 \%)$, four in twenty-one phalanges (19\%), and two in eight tibiae (25\%). The sample size for bison (6) and for the woodland muskox (4) is about the same. They are similar in size and body proportions, so the relatively high occurrence in Bison and not in Bootherium or the equally large American camel, Camelops, suggests that size alone is not the only factor. Although mammoths are represented by at least three individuals, virtually no postcranial elements have been recovered. Some behavior or other attribute of Bison must predispose it to joint disease.

DISH was observed in four taxa: Equus, Bison, Gulo, and Miracinonyx, but only as single examples in each.

One Panthera atrox skull and lower jaw, KUVP 31417 , manifested a high level of flat wear on the canines. The incisors were worn flat almost to the alveolae. It seems likely that this is the result of scavenging meat and connective tissue from carcasses and manipulation of bone in the mouth. A left femur, tibia and fibula, KUVP 33057, were probably part of this same individual. The medial condyle of the left femur and the matching medial condyle of the tibia were highly eburnated, 


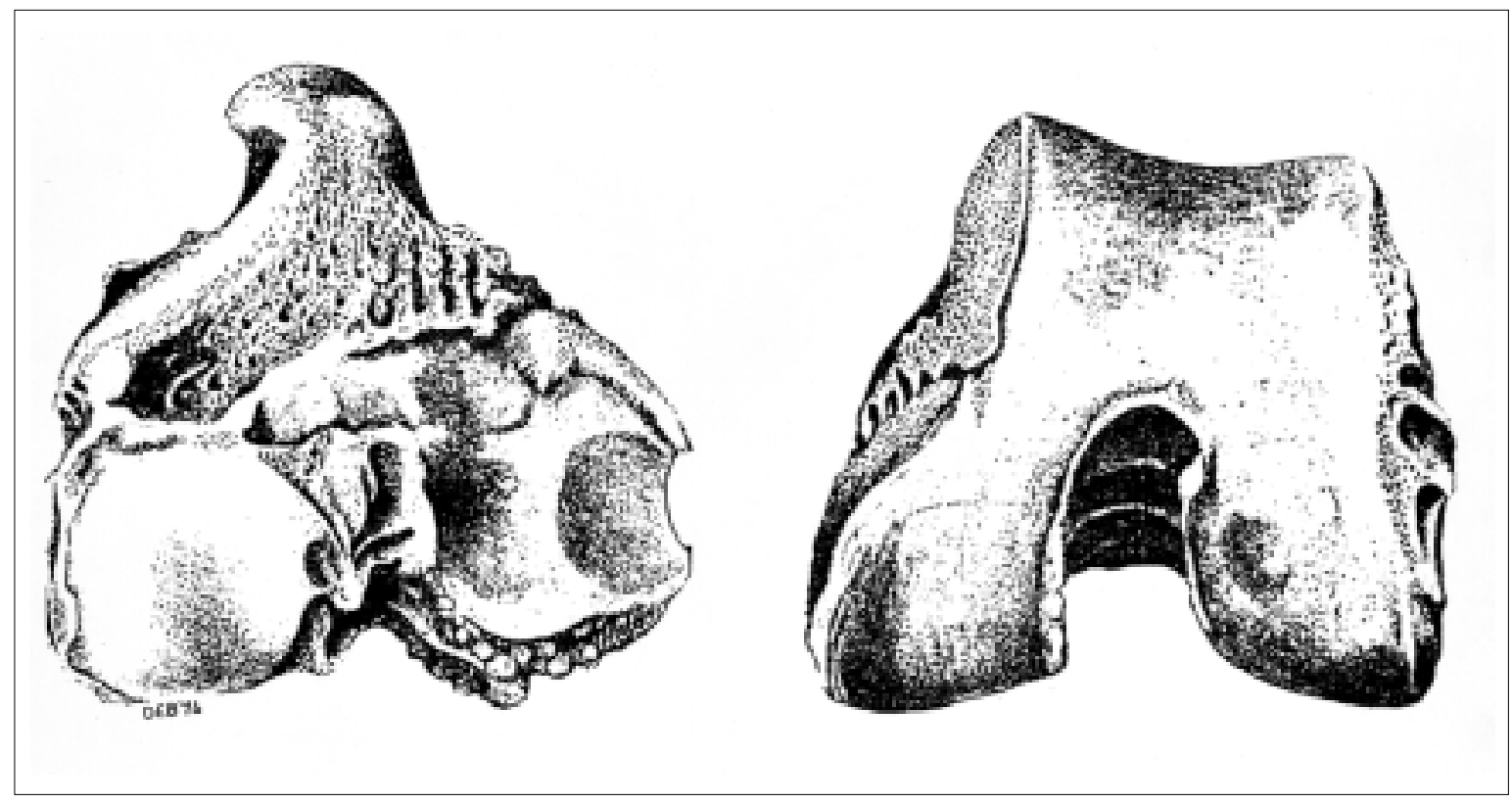

Figure 3 - Left knee, KUVP 33057, of American Lion, Panthera atrox. Proximal end of tibia and distal end of femur, showing the eburnated surface.

where the medial meniscus was worn through (Fig. $3)$. Extensive exostoses were visible around the joint margin on both bones. Similar tooth wear to KUVP 31417 was common in canids and ubiquitous in the Natural Trap Cave wolf sample. Canids are known to make better use of carcasses than do cats. The occurrence of the canid type of wear on the lion's teeth indicated that the individual was considerably disabled (15) and reduced to scavenging.

Scavengers also showed tooth breakage due to errors in handling bones. This was especially clear in specimens where bones have wedged across the mouth and broken teeth on both sides of the jaw. The wolverine, Gulo gulo, is a known scavenger. Its teeth manifested the typical flat-topped wear associated with animals that manipulate bones. In two instances out of four individuals, errors in bone manipulation resulted in tooth breakage. In both cases, the alveolae for the missing teeth healed. Breakage appeared due to the wedging of a long bone (or bone splinter) across the mouth at a high angle. In KUVP 51285 (Fig. 4) the right carnassial was missing, as were all the upper incisors except right $\mathrm{I}(3)$, indicating that a bone had been wedged between the right $\mathrm{I}(3)$ and the left canine. In KUVP 48116, a mandible, the left $\mathrm{P}(4)$ is missing as is right $\mathrm{P}(2)$, indicating a bone wedged between the right canine and $\mathrm{P}(3)$ and then extended across to between the left $\mathrm{P}(3)$ and $\mathrm{M}(1)$. The canines and incisors of this individual were worn flat and scavenging must have been its normal lifestyle.

Fragments of the broken roots remained for KUVP 51285, the right P(4) and for KUVP 48116, the right $\mathrm{P}(2)$ and left $\mathrm{P}(4)$. The alveolae were closed over by reparative bone. It seemed likely that pe-

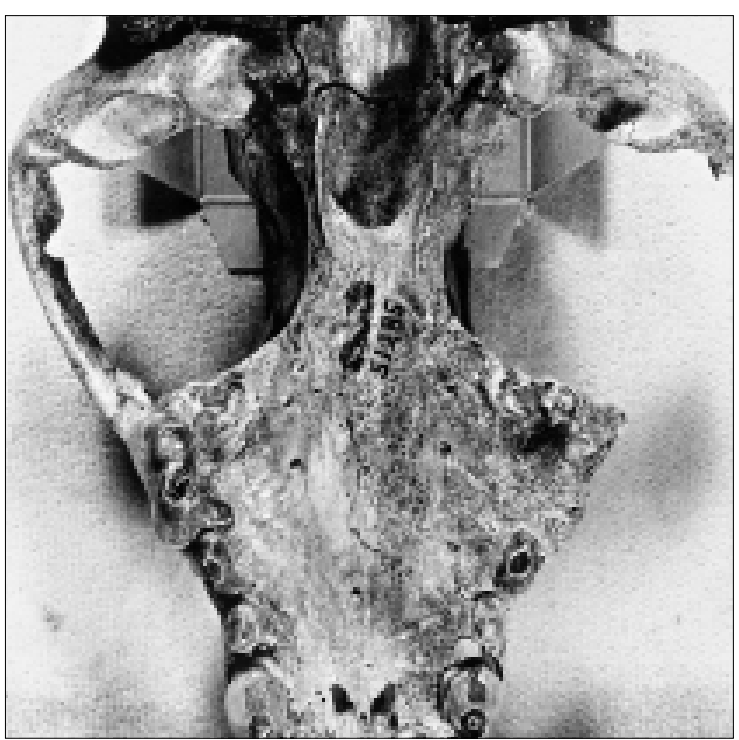

Figure 4 - Wolverine, Gulo gulo, jaws showing damage due to errors in bone manipulation: Skull, KUVP 51285, showing loss of right Premolar 4 and left Incisors 1-3, as well as right Incisors 1-2. 
riodontal disease followed the tooth breakage and may have resulted in the shedding of the tooth fragments and possibly adjacent healthy teeth in the case of at least some of the missing upper incisors of KUVP 51285, where only the right 1(3) remains.

\section{DISCUSSION}

\section{Erosive disease}

Erosive disease, undermining the articular surface is characteristic of chronic granulomatous infections $(4,11)$ (Table II). These include tuberculosis, brucellosis and fungal disease $(4,11,16-20)$. The predominantly monoarticular nature of the articular involvement noted in the fossil record is rare in human patients with forms of erosive arthritis (4, 11). The three affected genera appear especially at risk, whether by genetics or habitat. Habitat as a risk factor is well recognized in man.

Erosive disease in Natural Trap Cave was restricted to bovids, although the available sample size was much larger for horses and was as large for antilocaprids, as it was for either bison or muskox. This suggested that, whatever the cause of the disease, bovids are more susceptible to it. It was twice as common in muskox and bison as it is in the bighorn sheep, suggesting that some behavioral or habitat difference may be affecting its spread. It seems to be restricted to the feet (metacarpals). In terms of habitat preference, Bootherium finds are more restricted to forested areas than are those of Bison and are more commonly associated with bogs and marshy ground. The bighorn sheep would be more restricted to drier and open environments and would in that way more closely resemble the antilocaprid and the horses.

On the basis of phylogenetic susceptibility, likely organisms can be suggested. Among the phycomycetes, for example Absidia, Mucor, Mortierella, Rhinosporidum and Rhizopus predominantly affect cattle; Basidiobolus, Entomorphtora, Hyphomyces, and Rhinosporidium, horses; Rhizopus, swine; Entomorphthora, primates; and Rhinosporidium, dogs and fowl (18).

Table II - Documentation of chronic granulomatous infections in contemporary relatives of Natural Trap Cave*.

\begin{tabular}{|c|c|c|c|c|c|c|c|c|c|}
\hline Organism & Bovine & Sheep & Deer & Equine & Camel & Feline & Canine & Vole & Lagomorph \\
\hline $\begin{array}{l}\text { Mycobacterium } \\
\text { tubercolosis } \\
\text { bovis } \\
\text { avium** }^{* *} \\
\text { fortuitum } \\
\text { microti } \\
\text { paratuberculosis } \\
\text { thamnopheos } \\
\text { vaccae }\end{array}$ & $\begin{array}{l}+ \\
+ \\
+ \\
+ \\
+ \\
+ \\
+\end{array}$ & $\begin{array}{l}+ \\
+ \\
+ \\
+\end{array}$ & + & $\begin{array}{l}+ \\
+ \\
+\end{array}$ & + & $\begin{array}{l}+ \\
+ \\
+\end{array}$ & $\begin{array}{l}+ \\
+ \\
+\end{array}$ & + & $\begin{array}{l}+ \\
+ \\
+\end{array}$ \\
\hline $\begin{array}{l}\text { Brucella } \\
\quad \text { suis } \\
\quad \text { melitensis } \\
\quad \text { abortus } \\
\text { canis }\end{array}$ & $\begin{array}{l}+ \\
+\end{array}$ & + & + & & $\begin{array}{l}+ \\
+\end{array}$ & + & + & & \\
\hline $\begin{array}{l}\text { Sporotrichium } \\
\text { Cryptococcus } \\
\text { Coccidiomycosis } \\
\text { Histoplasmosis } \\
\text { Blastomyces } \\
\text { Adiaspiromyces } \\
\text { Mucormycosis } \\
\text { Erysipelothrix } \\
\text { Protothecosis }\end{array}$ & $\begin{array}{l}+ \\
+\end{array}$ & $\begin{array}{l}+ \\
+\end{array}$ & 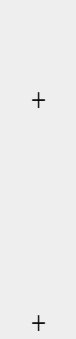 & $\begin{array}{l}+ \\
+ \\
+ \\
+\end{array}$ & + & $\begin{array}{l}+ \\
+ \\
+ \\
+ \\
+ \\
+ \\
+ \\
+\end{array}$ & $\begin{array}{l}+ \\
+ \\
+ \\
+ \\
+\end{array}$ & + & + \\
\hline
\end{tabular}


Bison infection has been specifically reported for Mycobacterium sp. and Brucella abortus $(18,20)$. Review of Table II indicates known patterns of infection in contemporary relatives of the genera represented in Natural Trap Cave.

Consideration that the affected genera were major food sources for American Indians leads to conjecture as to what diseases present in that group could explain the noted pathology and could the expression of disease in man be related to his food sources. Could endemic tuberculosis in American Indians reflect such a phenomena (21)?

The frequency of metacarpal erosion in Bison was uniform for 10,000 years, and probably exists at present. Indeed, its presence in a modern bison metacarpal (KU140290) in our collection suggests that likelihood. Brucellosis and Mycobacterium sp. $(18,20)$ are know to infect contemporary bison.

Perhaps the most important question with respect to identifying an etiologic agent relates to what is known with respect to agents of undermining articular surfaces. Among the mycobacteria, those reported as causing such erosions include $M$. tuberculosis (22-26), M. bovis $(21,22)$. Other organisms causing subchondral lesions grouped on features of their growth in culture include: Group I organisms (photochromogenic) such as $M$. kansasii $(28,29)$, Group II organisms (scotochromogenic) such as $M$. marinum (30), Group III organisms (non chromogenic) such as $M$.

triviale (31) and M. avium/intracellulare $(25,32)$, and Group IV (rapid growing) organisms such as M. terrae (33) and M. fortuitum (29).

Brucellosis classically produces such erosions (34), as well especially noted in the pre-antibiotic era $(17,35)$. Fifty-one percent of brucellosis infections in the United States are related to Brucella suis, $11 \%$ to B. melitensis, $21 \%$ to B. abortus, and $3 \%$ to $B$. canis (36). Isolatable from legumes (20), contamination during foraging is quite possible. At present, $1.9 \%$ of human brucellosis cases are related to wild animal (deer, caribou, feral swine) contact (37). This may underestimate the frequency of brucellosis contact, as positive skin tests for brucellosis were found in $9 \%$ of school children and $19.5 \%$ of adults from diverse areas as Kansas City and Minnesota, in a 1938 study (37).

Another classic organism to consider is Sporotrichum schenckii, $50 \%$ of sporotrichum joint infections are monoarticular, predominantly involving weight-joints, and frequently (34\%) producing juxta-articular cartilage erosion (38) and subchondral bone erosion (39). Other fungi, known to produce subchondral erosions, include Nocardia (40), Histoplasmosis (38, 41), Candida (42), Aspergillus (43), Coccidioidomycosis (44), and Blastomycosis $(18,45)$. Although Aspergillus is a common grain contaminant, it would be an unlikely etiologic agent as it tends to cause central (e.g., vertebral), not peripheral infections.

\section{Osteoarthritis}

Osteoarthritis was not found in any taxa with body weight below 25 kilograms. It was not common in any genus except Bison. We attempted to relate it to body mass and speed. The fastest animals in the fauna are the American cheetah and the pronghorn. The pronghorn showed no osteoarthritis and the cheetah only $6 \%$ (one involving the humeri). Although Bison is the second largest animal in the fauna and manifested the highest incidence of osteoarthritis, osteoarthritis was absent in Camelops and Bootherium, both of which are similar in size to Bison. It was also absent in the horses (Equus) which are smaller, but still relatively fast, large animals.

Recognition of the infectious etiology of the eroded Bison, Ovis and Bootherium metacarpals was the first step. Extraction of DNA and its amplification by polymerase chain reaction technology was the second step (46). Examining that amplified material revealed sequences matching the $M y$ cobacterium tuberculosis complex. Examining many DNA segments revealed a pattern unique to Mycobacterium tuberculosis (46). The next step, represented by this manuscript, was to identify its paleoepidemiology. Tuberculosis was a bovid disease in the Pleistocene.

\section{Teeth}

Bone manipulation resulted in tooth damage to two wolverines, and coupled with the flat teeth wear, was indicative of the important scavenging role of this genus. Carnivores were over-represented in Natural Trap Cave. This may be in part due to its acting as a baited trap, that would tend to concentrate carnivores, especially scavengers.

\section{ACKNOWLEDGEMENTS}

This project has been supported by NSF DEB 7521234 and by NGS 2709-83. The paper was critically read by R.W. Wilson, J. Hearst and T. Goodwin. 


\begin{abstract}
SUMMARY
Population data are presented for erosive arthritis, osteoarthritis, diffuse idiopathic skeletal hyperostosis (DISH), joint eburnation and dental injury in a fauna from Natural Trap Cave, Wyoming, represented by over thirty thousand bones from twenty-four different species. Erosive arthritis is limited to the bovids, Bison, Ovis and Bootherium. Erosive arthritis is also present in bison from the late Pleistocene Twelve Mile Creek site in Kansas and from an early Holocene site in Wisconsin. The restriction of the known Pleistocene occurrences to bovids indicate the presence of a pathogen that predisposes bovids to erosive arthritis. The pathogen was identified as Mvcobacterium tuberculosis. Osteoarthritis and DISH are rare in the Natural Trap Cave, although Bison shows a relatively high occurrence of the former. Tooth breakage due to errors in bone manipulation was a problem for carnivores and one lion, Pantera atrox, was apparently reduced by joint disease to a scavenging lifestyle.
\end{abstract}

Key words - Paleopatologia, osteoartrosi, artrite tubercolare, artriti erosive, DISH.

Parole chiave - Paleopathology, osteoarthritis, tubercular arthritis, erosive arthritis, DISH.

\section{REFERENCES}

1. Appelboom T. Proceedings of the Symposium on Art, History, and Antiquity of rheumatic diseases. Elsevier Edition, Brussels, Belgium, April 17-19, 1986.

2. Bourke JB. A review of the paleopathology of arthritic diseases. In: Diseases in Antiquity, ((Brothwell D and Sandison AT, eds.). Springfield, IL: Charles C. Thomas, 1967: 252-69.

3. Short CL. The antiquity of rheumatoid arthritis. Arthritis Rheum 1974; 17: 193-205.

4. Rothschild BM, Martin LD. Paleopathology: Disease in the Fossil Record. London: CRC Press, 1993.

5. Martin LD, Gilbert BM. Excavation at Natural Trap Cave. Trans Nebraska Acad Sci 1978; 6: 107-16.

6. Rogers RA, Martin LD. The 12 Mile Creek site: A reinvestigation. Amer Antiquity, 1984; 49: 757-64.

7. Pond AW. Wisconsin joins ranks of oldest inhabited areas in America. Wisconsin Archeol 1937; 17: 51-4.

8. Altman R, Alarcon G, Appelrouth D, Bloch D, Borenstein D, Brandt K, et al. Criteria for classification and reporting of osteoarthritis of the hand. Arthritis Rheum 1990; 33: 1601-10.

9. Altman R, Alarcon G, Appelrouth D, Bloch D, Borenstein D, Brandt K, et al. Criteria for classification and reporting of osteoarthritis of the hip. Arthritis Rheum 1991; 34: 505-14.

10. Altman R, Asch E, Bloch D, Bole G, Borenstein D, Brandt K, et al. Criteria for classification and reporting of osteoarthritis: Classification of osteoarthritis of the knee. Arthritis Rheum 1986; 29: 1039-49.

11. Resnick D, Niwayma G. Diagnosis of bone and joint disorder. Philadelphia: W.B.Saunders, 1988.

12. Rothschild BM. Rheumatology: A Primary Care Approach. New York: Yorke Medical Press, 1982.

13. Rothschild BM. Diffuse idiopathic skeletal hyperostosis as reflected in the Paleontologic record: dinosaurs and early mammals. Semin Arthritis Rheum 1987; 17: 119-25.

14. Rothschild BM. Diffuse idiopathic skeletal hyperostosis. Comp Ther 1988; 14: 65-9.

15. Martin LD, Gilbert BM. An American Lion, Panthera atrox, from Natural Trap Cave, North Central
Wyoming. Contrib Geology, Univ. Wyoming 1978; 2: 95-101.

16. Altner PL, Turner RR. Sporotrichosis of bones and joints. Clin Orthop 1970; 68: 138-48.

17. Gotuzzo E, Alarcon CS, Bocanegra TS, Carillo C, Guerra JC, Isaias R, et al. Articular involvement in human brucellosis: A retrospective analysis of 304 cases. Semin Arthritis Rheum 1982; 12: 245-51.

18. Jones RR Jr, Martin DS. B1astomycosis of bone. A review of 63 collected cases, of which 6 recovered. Surgery 1942; 10: 931-38.

19. Buchanan TM, Hendricks SL, Patton CM, Feldman RA. Brucellosis in the United States 1960-1972. Medicine 1974; 53: 427-39.

20. Roux J. Epidemiologie et prevention de la brucellose. Bull OMS, 1979; 57: 179-94.

21. Enarson DA, Fujii M, Nakielna EM, Grzybowski S. Bone joint tuberculosis: A continuing problem. Canad Med Assoc J 1979; 120: 139-45.

22. Berney S, Goldstein M, Bishko F. Clinical and diagnostic features of tuberculous arthritis. Am J Med 1972; 53: $36-42$.

23. Feldman F, Auerbach R, Johnston A. Tuberculous dactylitis in the adult. Am J Roentgenol 1971; 112: 460-79.

24. Jones TC, Hunt RD. Veterinary Pathology. Philadelphia: Lea \& Febiger, 1983.

25. Chapman M, Murray RO, Stoker DJ. Tuberculosis of bones and joints. Semin Roentgenol 1979; 14: 266-82.

26. Stroebel AB, Daniel TM, Lou JH, Leong JC Richardson $\mathrm{H}$. Serologic diagnosis of bone and joint tuberculosis by an enzyme-linked immunosorbent assay. J Infect Dis 1982; 146: 280-3.

27. Davies PD, Humphries MJ, Byfeild SP, Nunn AJ, Darbyshire JH, Citron KM, et al. Bone and joint tuberculosis. J Bone Jt Surg 1984; 66B: 326-30.

28. Maberry JD. Cutaneous infection due to Mycobacterium kansasii. JAMA 1965; 194:1135-8

29. Kelly PJ, Karlson AG, Weed LA, Lipscomb PR. Infection of synovial tissues by mycobacteria other than Mycobacterium tuberculosis. J Bone Jt Surg 1967; 49A: 1521-30.

30. Williams CS, Riorden DC. Mycobacterium marinum 
(Atypical acid-fast bacillus) infections of the hand. J Bone Jt Surg 1973; 55A: 1042-50.

31. Dechairo DC, Kittredge D, Meyers A, Corrales J. Septic arthritis due to Mycobacterium triviale. Am Rev Resp Dis 1973; 108: 1224-6.

32. Ellis W. Multiple bone lesions caused by avium-Battery mycobacteria. J Bone Jt Surg 1974; 56B: 323- 6.

33. Edwards MS, Huber TW, Bakor CJ. Mycobacterium terrae synovitis and osteomyelitis. Am Rev Resp Dis 1978; 117: 161-3.

34. Seal PV, Morris CA. Brucellosis of the corpus. J Bone Jt Surg 1974; 56B: 327-30.

35. Ploussard CN. Brucella infection of bones and joints. Am J Roentgenol 1951; 66: 910-4.

36. Fox MD, Kaufmann AF. Brucellosis in the United States 1965-1974. J Infect Dis 1977; 136: 312-6.

37. Wise RI. Brucellosis in the United States: Past, present, and future. JAMA 1980; 244: 2318-22.

38. Bayer A, Scott VJ, Guze GB. Fungal arthritis: III Sporotrichal arthritis. Semin Arthritis Rheum 1979; 9:66-74.

39. Crouot JE, Brewer NS, Tompkins RB. Sporotrichosis arthritis. Ann Intern Med 1977; 86: 294-7.

40. Belliveau RR, Geiger F. Lymphocutaneous Nocardia brasiliensis infection simulating sporotrichosis. West J Med 1977; 127: 145-245.

41. Key JA, Large AM. Histoplasmosis of the knee. J Bone Jt Surgery, 1942; 24: 281-90.

42. Gerster JC, Glauser MP, Delacretaz F, Nguyen T. Erosive Candida arthritis in a patient with disseminating candidiasis. J Rheumatol 1980; 7: 911-4.

43. Casscells SW. Aspergillus osteomyelitis of the tibia. J Bone Jt Surg 1978; 60A: 994-5.
44. Drutz DJ, Catanzaro A. Coccidioidomycosis. Am Rev Resp Dis 1978; 117: 727-71.

45. Gelmen MI, Everts CS. Blastomycotic dactylitis. Radiology 1973; 107: 331-2.

46. Rothschild BM, Martin LD, Lev G, Bercovier H, BarGal GK, Greenblatt C, et al. Mvcobacterium-tuberculosis-complex DNA from an extinct bison dated 17,000 years bp. Clin Infect Dis 2001; 33: 305-11.

47. Goslee S, Wolinsky E. Water as a source of potentially pathogenic mycobacteria. Am Rev Resp Dis 1976; 113: 287-92.

48. Wolinsky E, Rynearson TK. Mycobacteria in soil and their relation to disease-associate strains. Am Rev Resp Dis 1969; 97: 1032-7.

49. Benbrook EA, Bryant JB, Sauadin LZ. A case of blastomycosis in the horse. J Amer Veterin Med Assoc 1948; 112: 475.

50. Sarosi GA, Serstock DS. Isolation of Blastomyces dermatitidis from pigeon manure. Am Rev Resp Dis 1976; 114: 1179-83.

51. Menges RW. Blastomycosis in animals: A review of 116 canine cases. Veterin Med 1960; 50: 45-54.

52. Kubin M, Kruml J, Janku A. Experimental osteoarthritis in guinea pigs produced by nonchromogenic unclassified mycobacteria. Acta Tuberc Pneumol 1964; 44: 159-67.

53. Meissner G, Anz W. Sources of Mycobacterium avium complex infection resulting in human diseases. Am Rev Resp Dis 1977; 116: 1057-64.

54. Barbee MA, Ewert A, Davidson EM. Sporotrichosis in the domestic cat. Am J Pathol 1977; 86: 281-4.

55. Vogel H. Mycobacteria from cold-blooded animals. Ann Tuberc 1958; 77:823-38. 